\title{
Financial Ratio Analysis to Assess Financial Performance of the Hotel Industry
}

\section{Tjeng Gloria Santoso ${ }^{1 *}$, Supatmi ${ }^{2}$}

1,2 Universitas Kristen Satya Wacana, Salatiga, Indonesia

\section{ART ICLE INFO}

Article history:

Received July 02, 2021

Revised July 03, 2021

Accepted August 11, 2021

Available online August 25, 2021

Keywords:

Liquidity Ratio, Profitability Ratio, Activity Ratio, Leverage Ratio, Operational Ratio Hotel Industry

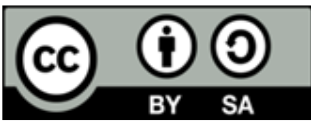

This is an open access article under the CC BY-SA license.

Copyright $(2021$ by Author. Published by Universitas Pendidikan Ganesha.

\begin{abstract}
A B S T R A C T
Analysis of financial performance can be implemented to all companies, including to hotel industries. For the last few years, there are many issues that income of hotel industry increases because of the soaring numbers of foreign and domestic tourists in Indonesia. This study aims to analyze financial ratio to assess the financial performance of hotel industry in 2015-2018. Research sample were 12 companies of 35 hotel industries that were listed in Indonesian Stock Exchange in 2015-2018. Analysis tool used in this research were liquidity ratio, profitability ratio, activity ratio, leverage ratio, and operational ratio. Research result showed good ratios; they were liquidity ratio that was indicated by current ratio, profitability ratio that was pointed by net profit margin, return on asset, and return on equity, also paid occupancy percentage on activity ratio. While the not good ratio, which was activity ratio was pointed by total asset turnover, then leverage ratio by equity multiplier, debt to asset ratio, and debt to equity ratio, also operational ratio which was showed through average room rate and food and beverage cost. Research result of hotel performance in 2015-2018 which is based on financial ratio, they are liquidity, activity, profitability, leverage, and operational, describes that hotel performance is fluctuated. Generally seen, a good ratio in this study is the liquidity ratio that is pointed by current ratio, then profitability ratio that are demonstrated by NPM, ROA, and ROE, also paid occupancy percentage in activity ratio.
\end{abstract}

\section{INTRODUCTION}

Analysis of financial performance can be implemented to all companies, including to hotel industries (Agustini \& Wirawati, 2019; Gunawan, 2019). For the last few years, there are many issues that income of hotel industry increases because of the soaring numbers of foreign and domestic tourists in Indonesia. For example, the income of Sahid Jaya International Hotel increases for $12.16 \%$ in 2017 to 2018 (Putra, 2019). The number of foreign tourists increases for 14\% in 2014-2018 as their number increases for 2.5 times or 15.81 million of persons in 2018 when it is compared to 2009 (Rais et al., 2019). The increasing number of tourists are highly influenced by tourism growth in Indonesia. Indonesia is included in the $9^{\text {th }}$ country with the fastest tourism growth in the world in the reign of Joko Widodo - Jusuf Kalla (Saputro \& Taufiequrrohman, 2018). The increased number of tourists bring impact to the country's foreign exchange income where tourism sector becomes the largest source of foreign exchange for the country. Besides that, the investors place their investment in stars hotels, restaurants, and short-term accommodation industries in certain areas where there are many places to visit by both domestic and foreign tourists (Humaidy, 2019; Leslie \& Russell, 2006). Profit increase of hotel industry in Indonesia should indicate performance increase of the company, therefore it needs a company financial analysis.

Financial performance is ability of the company in controlling its operational activities (Kurniadi et al., 2014; Trianto, 2017). Besides that, financial performance indicates the company management in accordance with the rules of good and correct financial application. Being concluded, financial performance is a result of decision made by the management to achieve the company goals in the effective and efficient ways. Financial ratio is a comparison of one data with other data in a financial report which are related to each other (Febriyanto \& Gusma, 2021; Trianto, 2017). From that comparison, an analyzer may draw a conclusion about financial condition of a company. Financial ratio is divided into some parts; they are liquidity ratio that refers to ability of the company to meet short term liabilities by using the easiest asset converted to cash, then activity ratioto measure the level of efficiency in the utilization of company 
resources, then the profitability ratio which provides an overview of the company's probability, and leverage ratio which describes the company's ability to fulfill all of its obligations (Syuhada et al., 2020). Other than that, operational ratio is used to help the management to analyze the operational department of the company especially in restaurants and hotels (Saepudin, P. \& Muslim, 2016).

A research in Ciater SPA \& Resort Hotel, Subang, showed high level of liquidity (Saepudin, P. \& Muslim, 2016). Besides that, ability of the company assets to guarantee debt increase and inventory turnover decrease and also the fluctuated earned profit margin. Then, return on asset and return on equity are still far to accelerate asset return or owner's investment and also from the operating ratio, it is known that average room rate is quite high when it is compared to other three stars hotels. While for the percentage of food and beverage cost, it tends to increase. The previous research explained that the financial performance of the Syariah Hotel "Al Badar" during the research period had a net profit margin ratio which was considered less because it was below the industry standard net profit margin, and the profitability ratio was still very far below the industry standard of return on assets (Muliana \& Nurbayani, 2019). A research in Local Water Company of Tegal Regency indicated fluctuated liquidity ratio, activity ratio increases, and operating expenses to income ratio decreases and profitability ratio increases every year (Sulistiowati \& Nurmansyah, 2017). Based on the previous research, it can be seen that financial ratio can be used to assess financial performance of a company.

Condition of this research is different from the previous researches which it does not only evaluate the financial performance, but also proves that tourism sector influences financial performance of hotel industry as it is assumed during the research period, hotel performance should show increasing trend because of government policy therefore the government can keep on focusing to improve tourism. In accordance with the aim of this research, then it is expected that this research results bring benefit to various parties. Theoretically, financial ratio is used to assess performance of a company, specifically hotel industry. Practically, this research result may serve as an information for the hotel industry to evaluate the company performance and be taken into account in decision making. Furthermore, investors may use this research as their consideration in selecting the correct hotels for their investment and this research also can help the government agencies to make the right policies related to hotel taxes.

\section{METHODS}

This research is a quantitative descriptive research that is research that describes the data during the research period to answer the formulation of the research problem (Sugiyono, 2014). The data used is quantitative data obtained from the financial statements of the hospitality industry listed on the (ISE) Indonesian Stock Exchange period 2015-2018 which is calculated according to the ratio used in this study. While research sample were hotel industries which were listed in ISE that had provided complete financial reports and used Rupiah currency and did not delisting during observation period. There are 35 research populations but only 12 of them which meet the sample criteria as in Table 1.

Table 1. Research Sample

\begin{tabular}{lc}
\hline \multicolumn{1}{c}{ Company Name } & Code \\
\hline Bukit Uluwatu Villa Tbk & BUVA \\
Hotel Mandarine Regency Tbk & HOME \\
Saraswati Griya Lestari Tbk & HOTL \\
Island Concepts Indonesia Tbk & ICON \\
Indonesian Paradise Property & INPP \\
Jakarta International Hotel \& Development Tbk & JIHD \\
Jakarta Setiabudi Internasional Tbk & JSPT \\
MNC Land Tbk & KPIG \\
Pembagunan Graha Lestari Indah & PGLI \\
Pudjiadi \& Sons Tbk & PNSE \\
Red Planet Indonesia Tbk & PSKT \\
Sahid Jaya International Hotel Tbk & SHID \\
\hline \multicolumn{2}{c}{ Total Sample } \\
\hline
\end{tabular}

Analysis techniques were divided into 2 parts, financial ratio analysis of the hotels entirely and financial ratio analysis per hotel. The entire financial ratio of the hotels was conducted by analyzing the average of every ratio and pointed which hotel had the best performance and the worst performance in that ratio. While for financial ratio analysis per hotel, trend analysis was performed for every financial ratio of each hotel. Based on those analysis, a conclusion will be drawn based on the research result. 


\section{RESULTS AND DISCUSSIONS}

\section{Results}

Description of Statistics

Table 3 below describes data distribution for every variable in this research:

Table 3. Description of Statistics

\begin{tabular}{ccccc}
\hline Research Variable & Maximum Value & Minimum Value & Average Value & Deviation Standard \\
\hline CR & 6,87 & 0,20 & 1,62 & 1,37 \\
NPM & 1,90 & $-1,21$ & 0,08 & 0,44 \\
ROA & 0,13 & $-0,15$ & 0,01 & 0,05 \\
ROE & 0,16 & $-0,49$ & 0,01 & 0,10 \\
TATO & 0,52 & 0,06 & 0,21 & 0,13 \\
POP & 0,88 & 0,28 & 0,61 & 0,17 \\
EM & 3,21 & 1,12 & 1,70 & 0,56 \\
DAR & 0,69 & 0,11 & 0,36 & 0,16 \\
DER & 2,21 & 0,12 & 0,71 & 0,56 \\
ARR & 790679 & 223208 & 544300 & 183093 \\
F\&B COST & 0,93 & 0,09 & 0,43 & 0,19 \\
\hline
\end{tabular}

Financial ratio analysis of each hotel will be described through its performance analysis result in the following explanations.

\section{Bukit Uluwatu Villa Tbk (BUVA)}

BUVA liquidity level is not in good condition, because CR value decreases higher than the increasing one and the value is far below the average of all hotels. NPM of BUVA presents that there is loss occurred and profit value is below the average, therefore it signs dissatisfactory result. Then, ROA value of BOVA also loses and the value is lower than the average of all hotels. Still, ROE of BUVA fluctuates and lower than the average thus it shows poor investment return. TATO of BUVA indicates averagely increasing movement which explains that company ability in generating sales from assets continues to increase. However, TATO of BUVA is still below TATO average value of all companies so that it still indicates poor results. EM of BUVA presents fluctuated value and higher than average value of all hotels, in which it signs that EM of BUVA is not good and it indicates that majority assets of the company is financed by debt. DAR of BUVA describes same movement with EM and higher value than the average value of all companies. That condition strengthens EM ratio conclusion where BUVA still finances majority of its assets with debt and has high risk in paying off the long-term debt. BUVA has high level of debt because DER value is higher than the average and the value is fluctuated. F\&B cost of BUVA has good value because although it decreases from 2015 to 2018 , but the value is still above the average value of all companies.

\section{Hotel Mandarine Regency Tbk (HOME)}

CR of HOME has poor liquidity level because its big amount of current debt, exceeds the current assets. Ratio value of NPM HOME is fluctuated, even face a loss in 2018 and the value is below the average value therefore it indicates that HOME is dissatisfactory in generating income from its sales. ROA ratio has similar movement with NPM, therefore 2016 is a year with the highest profit from assets usage of other years. Like the previous ratio, ROE of HOME has the same movement which signs that the company can't manage its capital well. The fluctuated TATO of HOME explains sales income from the company assets is unstable. However, the value it is resulted every year is above the average value, then it is concluded that although it is unstable, TATO of the company shows good condition. The POP value of HOME is below the average of all hotels, therefore it indicates only a few guests stayed in this hotel. On leverage ratio, EM value of HOME increase every year but it is still below the average of all hotels which means EM of HOME is in good condition. DAR value describes increasing value for each year but still below the average of other companies, then DAR and EM value indicate that perhaps the company assets continue to be financed by debt. DER has similar movement with EM and DAR and the value is below the average, then it illustrates that company debt continues to increase but does not exceed the average limit. ARR of HOME is good because its yearly average is above the average of all companies, although it decreases in 2016 and 2018. While for the F\&B cost, it also presents fluctuated value and it is below the average limit. It signs that the rising cost is still in good limit. 


\section{Hotel Saraswati Griya Lestari Tbk (HOTL)}

CR of HOTL increases every year, but until 2017 the value is below the average of all hotels. In the meantime, liquidity level can be said it is getting better every year in which by 2018 the value is above the average limit of all hotels. Then, the value of profitability ratio of HOTL is above the average in 2015 and 2017 and it is below the average in 2016 and 2018. It signs that profitability of HOTL generates profit and resulting in dissatisfactory capital management. TATO ratio of HOTL shows that the company has good ability in generating sales from the company assets. However, the resulting value is not eligible yet to be said as a good company because it is below the average of all hotels. Leverage ratio of HOTL presents increasing result every year and all the values are above the average. It means that the company is in poor condition because the increasing value is interpreted as debt that the company used is bigger than the capital to fund the company and the debt value exceeds normal limit in the hotel industry. Next, for the F\&B cost ratio, it shows increasing value for every year. It is not a good condition because the expenses continue to increase but it generates unstable profit when it is seen from profitability ratio.

\section{Island Concepts Indonesia Tbk (ICON)}

Liquidity ratio of ICON presents good liquidity level, because the value increases every year. Profitability ratio during observation period is quite good because the value increases for the last 2 years. Based on those three profitability ratios, ICON is in a good condition because its profit increase in which its average exceeds the average of the hotel industries. Then, for the activity ratio, TATO and POP of ICON shows higher result than the average of the companies in this research although they decrease in certain years. It indicates that the company is in good condition because it is able to generate sales from the company assets and also able to invite many guests to the hotel. Leverage ratio of ICON shows decreasing value in the last 2 years. Although the leverage value decreased, but the resulted value was higher from the average limit of all hotels. It indicates dissatisfactory result because it uses debt higher than other companies to finance the company and has high risk in paying off its debt. F\&B Cost ratio of ICON is fluctuated and the value exceed the average level of all companies. It signs that the incurred cost is quite big.

\section{Indonesian Paradise Property (INPP)}

CR ratio of INPP shows poor result because the value is fluctuated and its average value is below the average of all hotels. NPM and ROA ratios presents that the net profit and profit from the assets are quite good. Meanwhile, ROE indicates that rate of investment return is pretty good and the company is considered capable to manage its capital well. TATO ratio of INPP averagely decreases and the value is below the average. It signs that INPP is not good enough in generating sales from the company assets. Other than that, POP of INPP shows reverse value where its average value during observation period increases and it is above the average. It denotes that INPP has good occupancy rate. EM leverage ratio of INPP increases for the last 2 years. This movement indicates the company's well ability to use the shareholders capital in managing the assets, but the value is still below the average of all hotels. Next, DAR and DER are seen increased every year although the values are below the average of all hotels. It tells the company capability to pay off its long-term debt continues to increase and capital rate that it has is higher than the debt it is used to fund the company. Operational ratio, which are ARR and F\&B Cost ratios presented the values that were above the average of all hotels. This ARR value signifies that the company is in good condition, but F\&B Cost implies that the company can't control the cost of food and beverage yet.

\section{Jakarta International Hotel \& Development Tbk (JIHD)}

CR of JIHD signs a not good result because the decreasing value is bigger than the increasing value. It shows that the company has poor liquidity rate where the average of current debt that it has is higher than its current asset and the value is far below the average. NPM ratio indicates fluctuated value and its average is above the average value. It implies that the company is quite good in generating profit. ROA and ROE ratios of JIHD also denotes fluctuated rate and its average is above the average of all hotels. It means that rate of return on asset is quite efficient and the company earns sufficient profit from the investments of the shareholders. TATO ratio of JIHD indicates fluctuated movement and the value is above the average of all hotels that are observed. Therefore, the company of JIHD hotel has good capability in generating sales from the assets that it has. Ratio of EM, DAR, and DER of JIHD have decreasing movement every year and the values implies that they are below the average of the entire hotels. EM indicates that JIHD is in good condition because in financing the assets, the company uses more of its capital than debt. DAR and DER are good because the company can pay off its long-term debt and has lower debt rate when it is compared to its capital. 


\section{Jakarta Setiabudi Internasional Tbk (JSPT)}

CR of JSPT is above the average value of all hotels therefore it denotes that the company is quite good in maintain its liquidity rate. Ratio of NPM, ROA, and ROE of JSPT increase in the last 2 years and the values are higher than the average value of all hotels. Therefore, the company is concluded has good profitability rate because it presents the net income that it earns from sales, then its return on asset and the managed capital to profit that is derived from the investment all are in good condition. TATO ratio of JSPT indicates higher value than the average value of all hotels although there is a year where the company value decreases but it is not lower than the average value. It signs a good condition where the company can maintain its stability from its capability to generate sales of company assets. JSPT leverage ratio averagely has increasing value and lower from the average value of all hotels. EM ratio shows that capital usage from the shareholders for company assets funding is good because although its value increases, but the company does not exceed the average limit of other companies. DAR of JPST points that the company can pay off its long-term debt when it is compared to most of other hotels. DER demonstrates that debt rate is lower than the capital that it has. It signs that JSPT is able to fund the company with majority capital it has.

\section{MNC Land Tbk (KPIG)}

CR of KPIG presents a very high value when it is compared to average CR of all hotels. The higher value signs that the company has good liquidity where the company can cover its current debt with the company current asset. Ratio in this profitability shows that the company has good performance in earning profit from sales, assets, and investment, but for the last 2 years during observation period, the company presents performance decrease. TATO ratio of KPIG exhibits decreasing value for every year and the value is far below the average of all hotels. Those indicates that KPIG capability is dissatisfactory and continues to decrease in generating sales from the company assets. Then for KPIG leverage ratio, the value is fluctuated and below the average value of all hotels in this research. It indicates that the company performance through this ratio is good where EM ratio points that most of company assets are financed by shareholders capital, subsequently DAR presents that KPIG is able to pay off its long-term debt and funds its assets with majority of its capital, while DER shows that debt rate that it is used is lower than the capital to fund the company.

\section{Pembangunan Graha Lestari Indah (PGLI)}

CR of PGLI demonstrates higher value than average value of all hotels and average of current asset is higher than current debt. It shows that PGLI has good liquidity rate. The three profitability ratios are very good because their value increase every year, but its average value is still below the average of all hotels. It is good because it signs that the company tries to increase its earning from sales. Subsequently, ROA and ROE of PGLI are very good because all per yearly values are above the average of all hotels. This ROA and ROE points a good return on assets and capital management that can make a good return on investment. TATO ratio of PGLI shows company assets sales is in good condition because the value is above the average of all hotels although it decreases for the last 2 years. POP ratio presents a lack of hotel visitors because the value is lower than the average of all hotels. The three leverage ratios have averagely decreasing value and lower from the average of all hotels. It signs that the company is in a good condition where EM ratio indicates that the company can manage the capital from the shareholders, then DAR points that majority of the assets are financed by the capital, and DER indicates higher capital rate than the debt that is used for the company funding. ARR ratio has averagely increasing rate and it is higher than the average of all hotels where it describes that the company is in good condition. Meanwhile, value of F\&B Cost ratio is below the average so that the company is considered well in that expenses.

\section{Pudjiadi and Sons Tbk (PNSE)}

The CR value of PNSE fluctuates and it is below the average of all hotels. The company is less liquid where current debts of the company is higher than its current assets, therefore the company can't pay off its due debt. Profitability ratio value of PNSE is also fluctuated then it faces a loss thus the company is considered poor in generating sales profit, company assets usage, and profit for the investors. TATO ratio shows higher value than the average of all hotels although the value decreases for 2 years which then demonstrates that the company can generate assets sales. POP ratio denotes lower value from the average of all hotels which signs the number of hotel guests of PNSE is below the average. The value of each leverage ratio describes quite good value even though it increases and above the average of all hotels but it decreases again and in 2018 the company has performance improvement where the result can be lower than the average. ARR and F\&B Cost ratios present the values that below the average of all hotels. Those values indicate that the company is not in good condition because it is still below the average of all hotels. At the meantime, F\&B Cost ratio is good because the expenses is lower than the average. 


\section{Red Planet Indonesia Tbk (PSKT)}

CR of PSKT shows less liquid result because it experiences value decrease with low average when it is compared to the average of all hotels, then the conclusion is PSKT is not good enough in paying its due debt. The three profitability ratio indicates negative value therefore the company is deemed to suffer loss every year and it does not get profit from the asset investment and investment owner. The value of TATO ratio which is below the average of all hotels indicates that the company hasn't maximal yet in performing asset sales turnover. Then, ratio of POP shows good value because it is higher than the average which means there are more visitors who choose PSKT than majority of the hotels that are observed. PSKT has quite good leverage ratio because the value decreases from 2015-2017 although it increases again in 2018. EM ratio of PSKT denotes increasing ability of the company in using the capital from the investors. Then DAR also shows the company assets that are funded by debt started to decrease, DER also describes improvement where the debt is smaller than the capital in 2017 and 2018. PSKT operational ratio explains that ARR ratio is poor because the value is lower than the average of all hotels. Other than that, F\&B Cost ratio also shows poor condition because it's high increasing value in 2017 and 2018 that exceeds the average value.

\section{Hotel Sahid Jaya International Tbk (SHID)}

CR of SHID increased for the last 2 years and the value reaches more than the average of all hotels. This CR explains good rate of liquidity although in 2016 the value decreases but current debt that should be met is lower than current assets. For the profitability ratio, the resulted value is good because it increases every year. However, that value does not reach the average of all the observed hotels therefore condition of the company in generating profit, profit from asset investment or investment owner is still very less. Ratio of TATO and POP of SHID presents poor results where the value is far below the average of all hotels. It indicates that SHID is not good yet at generating asset sales and only a few rooms that are occupied. The increasing EM ratio in 2016 and 2017 signs that debt usage in asset funding increase. DAR also increases in 2017 where the value is above the average of all hotels until 2018. It explains poor ability of the company in paying off its long-term debt. DER shows an increasing movement which means that debt rate that is used for the company funding averagely increases when it is compared to the capital from shareholders. ARR ratio describes good condition because its average value is above the average of all hotels. In the meantime, F\&B Cost has good condition as its average value is still below the average which explains that the company can control the expenses.

\section{Discussion}

Liquidity ratio is the company's ability to meet maturing debt (Nuriasari, 2018; Widayanti et al., 2016). This ratio is important because if the company fails to pay the debt, it can cause the company to go bankrupt. Average value of hotel liquidity ratio which is proxied by current ratio has a value of 1.62. It means that averagely all hotels are able to pay off their current debt well because their number of current assets are bigger than their current liabilities. The lowest value is 0.20 belonged to Saraswati Griya Lestari Hotel in 2015 and the highest is MNC Land Hotel in 2017 for 6.87. It explains that KPIG has the best liquidity performance among other hotels with its ability to pay off its current debt 6.87 times by using current assets that it has.

Profitability ratio is the company's ability to earn profits in relation to sales, total assets and own capital (Sumanti \& Mangantar, 2015; Winanti, E. et al., 2017). Profitability ratio is proxied by 3 ratios. First, net profit margin in which the average value was 0.08 that means the hotel industry can generate net profit $8 \%$ for their total revenues. The lowest value $-1.21 \%$ is Red Planet Indonesia Hotel in 2015 and the highest $1.90 \%$ is MNC Land Hotel in 2016. Profitability ratio is also proxied by ROA ratio and ROE ratio where average ROA for 0.01 which means it creates profit for $1 \%$ from the assets that are used. Meanwhile, ROE value shows 0.01 that explains hotel industry creates $1 \%$ profit for the shareholders. The lowest ROA -0.15 is Red Planet Indonesia Hotel in 2015 and the highest 0.13 is MNC Land Hotel in 2016. Other than that, the lowest ROE -0.49 is Red Planet Indonesia in 2015 and the highest 0.15 is MNC Land Hotel in 2016.

Activity ratio is a ratio that measure the effectiveness of the company in utilizing all company resources (Agustini \& Wirawati, 2019; Sunarya, 2020). All of these activity ratios involve comparisons between the level of sales and investment in various types of assets. Activity ratio is proxied by 2 ratios, total asset turnover and paid occupancy percentage. TATO ratio average value is 0.21 that means hotel industry can generate $21 \%$ sales from total assets they have. The lowest TATO value is 0.06 of Red Planet Indonesia Hotel in 2016 and the highest value 0.52 is Pudjiadi and Sons Hotel in 2015. Then, the average of POP ratio is 0.61 which describes that averagely hotel industries are good enough because from total numbers of available rooms, $61 \%$ of them are occupied. Furthermore, the highest POP 0.88 is Island Concept Hotel in 2015, 2016, and 2017, while the lowest POP is Mandarine Regency Hotel in 2018 for 0.28. 
Leverage ratio is used to measure the extent to which the company's assets are financed with debt (Sari \& Hutagaol, 2009; Shintia, 2017). This means how much debt burden is borne by the company compared to its assets. In a broad sense it is said that the leverage ratio is used to measure the company's ability to pay all its obligations, both short term and long term if the company is dissolved (liquidated). Leverage ratio is proxied by equity multiplier, debt to asset ratio, and debt to equity ratio. EM has a value for 1.70 which means that assets comparison to equity in hotel industries in Indonesia is 1.70 . The lowest and the highest EM is Red Planet Indonesia Hotel for 1.12 times in 2017 and 3.21 times in 2015. Besides EM, average of DAR is 0.36 that describes hotel industry has $36 \%$ debt which influences the assets management. In the meantime, the highest DAR for 0.69 is Saraswati Griya Hotel in 2018 and the lowest 0.11 is Red Planet Indonesia Hotel in 2017. DER has average value for 0.71 that indicates comparison to debt and equity that is used for the operational of the hotel industry is $71 \%$. Other than that, the lowest and the highest DER is Red Planet Indonesia Hotel for 0.12 in 2017 and 2.21 in 2015.

Operational ratios are used to assist management in analyzing company operations, especially in the hospitality sector. Operational ratio that is proxied through average room rate has average value for Rp. 544,300; it means that average price of room sold is Rp. 544.300. Then the highest ARR is Sahid Jaya International Hotel which is Rp. 790,679.00 in 2018 and the lowest is Red Planet Indonesia Hotel for Rp. $223,208.00$ in 2016. Besides ARR, operational ratio is also proxied by food and beverage cost ratio where the average was 0.43 that is interpreted that the cost to produce food and beverage in the hotel industry is $43 \%$ from the total sales of food and beverage. The lowest F\&B cost is Sahid Jaya International Hotel for 0.09 in 2016 and the highest is Red Planet Indonesia Hotel for 0.93 in 2017. Limitation of this research is that not all data to calculate financial ratio of the hotel industry that is used in this research are available, such as paid occupancy percentage, average room rate, and food and beverage cost. Those make some financial ratio can't be compared to all sample hotels in this research. It is expected that future research can continue this study by getting more complete data such as occupancy data, average room rate, and food and beverage cost for all observed hotels in order to get more accurate value and to measure financial performance better.

\section{CONCLUSION}

Research result of hotel performance in 2015-2018 which is based on financial ratio, they are liquidity, activity, profitability, leverage, and operational, describes that hotel performance is fluctuated. Generally seen, a good ratio in this study is the liquidity ratio that is pointed by current ratio, then profitability ratio that are demonstrated by NPM, ROA, and ROE, also paid occupancy percentage in activity ratio. Meanwhile, the not good ratio which is the activity ratio is explained by total asset turnover, then leverage ratio by EM, DAR, and DER also operational ratio that are denoted by average room rate and food and beverage cost. Financial ratio that is used in this study may reflect financial performance of the hotels. It can be seen from the research result which describes that every ratio, that gets fluctuated result, shows the good and bad performance of the hotel performance. Based on the research result, it is suggested for the hotel industry to pay attention to income and expenses to make it more efficient in paying the company liabilities. Besides that, it is expected to considered cost calculation and business development that will be executed in certain period to see whether it is effective and efficient or not. For the investors, they are expected to be smarter in selecting companies to earn investment profit. While for the government, especially Ministry of Tourism and Creative Economy, this result may be used as a consideration to improve and to build tourism destinations, either from infrastructure, show, natural view, and others that are sold in those areas to support the hotel industry development.

\section{REFERENCES}

Agustini, N. W., \& Wirawati, N. G. P. (2019). Pengaruh Rasio Keuangan Pada Financial Distress Perusahaan Ritel Yang Terdaftar di Bursa Efek Indonesia (BEI). E-Jurnal Akuntansi, 26, 251. https://doi.org/10.24843/eja.2019.v26.i01.p10.

Febriyanto, F., \& Gusma, R. S. (2021). Analisis Rasio Keuangan Dalam Memprediksi Perubahan Laba Pada Perusahaan Manufaktur Yang Terdaftar Di Bursa Efek Indonesia (BEI). Jurnal Ilmu Manajemen Retail Universitas Muhammadiyah Sukabumi, 2(1), 25-30. https://www.jurnal.ummi.ac.id/index.php/jimat/article/view/1165.

Gunawan, A. (2019). Analisis Kinerja Keuangan Pada Perusahaan Plastik dan Kemasan yang Terdaftar di Bursa Efek Indonesia. Jurnal KRISNA: Kumpulan Riset Akuntansi, Vol. 10, N(Kinerja Keuangan), 109115.

Humaidy, A. (2019). Analisis Pengaruh Sektor Pariwisata Terhadap Pendapatan Asli Daerah (PAD) Kota 

Manado.
Jurnal
Berkala
Ilmiah
Efisiensi,
$19(4)$.

https://ejournal.unsrat.ac.id/index.php/jbie/article/view/26566.

Kurniadi, A., Achsani, N. A., \& Sasongko, H. (2014). Kinerja Keuangan Berbasis Penciptaan Nilai, Faktor Makroekonomi, dan Return Saham Sektor Pertanian. Jurnal Manajemen Dan Kewirausahaan, 16(2), 141-152. https://doi.org/10.9744/jmk.16.2.141-152.

Leslie, D., \& Russell, H. (2006). The importance of foreign language skills in the tourism sector: A comparative study of student perceptions in the UK and continental Europe. Tourism Management, 27, 1397-1407.

Muliana, M., \& Nurbayani. (2019). Analisis Profitabilitas Untuk Mengukur Kinerja Keuangan Manajemen Hotel Syariah "Al Badar" Di Kota Makassar. SEIKO : Journal of Management \& Business, 3(1), 1. https://doi.org/10.37531/sejaman.v3i1.466.

Nuriasari, S. (2018). Analisa Rasio Likuiditas Dalam Mengukur Kinerja Keuangan PT. Mustika Ratu, Tbk (Tahun 2010-2016). Jurnal Riset Bisnis Dan Investasi, 4(2), 1. https://doi.org/10.35697/jrbi.v4i2.1181.

Rais, A. N., Rousyati, R., Thira, I. J., Kholifah, D. N., Purwati, N., \& Kristania, Y. M. (2019). Evaluasi Metode Forecasting pada Data Kunjungan Wisatawan Mancanegara ke Indonesia. EVOLUSI: Jurnal Sains Dan Manajemen, 8(2). https://doi.org/10.31294/evolusi.v8i2.8971.

Reza, M., \& Kartawinata, B. R. (2015). Analisis Perbandingan Kinerja Keuangan Pada Industri Hotel Yang Terdaftar Di Bei Menggunakan Rasio Likuiditas, Leverage, Profitabilitas, Manajemen Aset Dan Nilai $\begin{array}{llll}\text { Pasar. } & \text { EProceedings } & \text { Management, } & \text { 2(3). }\end{array}$ https://openlibrarypublications.telkomuniversity.ac.id/index.php/management/article/downloa d/9205/9071.

Saepudin, P. \& Muslim, S. (2016). Analisis Rasio Keuangan Untuk Menilai Kinerja Hotel Ciater SPA \& Resort Subang. Journal of Chemical Information and Modeling, 53(9), 1689-1699. https://doi.org/10.1017/CB09781107415324.004.

Saputro, A., \& Taufiequrrohman, T. (2018). Investasi dalam Bingkai Politik Luar Negeri Pemerintahan Jokowi Jilid Satu dan Dampaknya bagi Masyarakat Indonesia. PERSPEKTIF, 10(2), 450-466. http://www.ojs.uma.ac.id/index.php/perspektif/article/view/4612.

Sari, L. A., \& Hutagaol, Y. (2009). Debt to Equity Ratio, Degree of Operating Leverage Stock Beta and Stock Returns of Food and Beverages Companies on the Indonesian Stock Exchange. Binus Journal, 2(2), 368.

Shintia, N. (2017). Analisis Rasio Solvabilitas Untuk Menilai Kinerja Keuangan Terhadap Asset dan Equity Pada PT Bank Rakyat Indonesia (PERSERO) Tbk Periode 2012-2015. At-Tadbir: Jurnal Ilmiah Manajemen, 1(1), 41-63. https://elibrary.unikom.ac.id/id/eprint/3057/.

Sugiyono. (2014). Metode Penelitian Pendidikan Pendekatan Kuantitatif, Kualitatif, dan R\&D. Alfabeta.

Sulistiowati, S., \& Nurmansyah, A. L. (2017). Analisis Laporan Keuangan Untuk Menilai Kinerja Keuangan Pada Perusahaan Daerah Air Minum Kabupaten Tegal. Monex: Journal Research Accounting $\begin{array}{lll}\text { Politeknik Tegal, 6(1), 236-240. } & \text {. }\end{array}$ http://ejournal.poltektegal.ac.id/index.php/monex/article/view/456.

Sumanti, J. C., \& Mangantar, M. (2015). Analisis Kepemilikan Manajerial, Kebijakan Hutang dan Profitabilitas Terhadap Kebijakan Dividen dan Nilai Perusahaan Pada Perusahaan Manufaktur yang Terdaftar di BEI. Jurnal EMBA, 3(1), 1141-1151.

Sunarya, K. Y. (2020). Analisis Rasio Profitabilitas dan Rasio Aktivitas Serta Pengaruhnya Terhadap Harga Saham (Studi Kasus Pada PT Hanjaya Mandala Sampoerna Tbk). Universitas Sangga Buana YPKP Bandung.

Syuhada, P., Muda, I., \& Rujiman, F. N. U. (2020). Pengaruh Kinerja Keuangan dan Ukuran Perusahaan Terhadap Financial Distress Pada Perusahaan Property dan Real Estate di Bursa Efek Indonesia. Jurnal Riset Akuntansi Dan Keuangan, 8(2), 319-336. https://doi.org/10.17509/jrak.v8i2.22684.

Trianto, A. (2017). Analisis Laporan Keuangan Sebagai Alat Untuk Menilai Kinerja Keuangan Perusahaan Pada Pt . Bukit Asam (Persero) Tbk Tanjung Enim. Ilmiah Ekonomi Global Masa Kini, 8(03), 2-3. https://doi.org/10.36982/jiegmk.v8i3.346.

Widayanti, L., Triaryati, N., \& Abundanti, N. (2016). Pengaruh Profitabilitas, Tingkat Pertumbuhan Perusahaan, Likuiditas, Dan Pajak Terhadap Struktur Modal Pada Sektor Pariwisata. None, 5(6), 249499.

Winanti, E., Nurlaela, S., \& Titisari, K. H. (2017). Pengaruh Rasiolikuiditas, Rasio Produktivitas, Rasio Profitabilitas, Dan Rasio Solvabilitas Terhadap Peringkat Sukuk. Jurnal Akuntansi Dan Pajak, 18(01), 130-139. https://doi.org/10.29040/jap.v18i01.90. 